\title{
Examination of the Biomark assay as an alternative to Oncotype DX for defining chemotherapy benefit
}

\author{
JINKYOUNG KIM, AEREE KIM and CHUNGYEUL KIM \\ Department of Pathology, Korea University Guro Hospital, Guro-gu, Seoul 08308, Republic of Korea
}

Received July 9, 2018; Accepted November 9, 2018

DOI: $10.3892 / \mathrm{ol} .2018 .9784$

\begin{abstract}
Currently the 21-gene recurrence score (RS) assay called Oncotype DX is recommended by the National Comprehensive Cancer Network guideline for defining the benefit of chemotherapy. To overcome the cost disadvantages of the Oncotype DX assay and the turnaround time, a multigene assay was examined to compare the correlation of the RS and the predicted score (PS) of the present study. Paraffin-embedded tissues of 50 cases with early-stage estrogen receptor (ER)-positive breast cancer, who underwent the Oncotype DX test were used. A total of 149 candidate genes with high correlation to the RS were identified, in another project (Lee et al, unpublished data). Reverse transcription-quantitative polymerase chain reaction biomark assays were conducted using the dynamic array integrated fluidic circuit and the correlation analysis was performed with BRB ArrayTools. A predictive model was developed by the coefficient and gene expression, and 41 genes were identified. If the cut-off was $\geq 18$, the predicted model was $18 / 50$ cases, and the RS was 19 , indicating that the differential rate of predicted response against RS was $2 \%$. If the cutoff was $\geq 11$, the predicted model was $38 / 50$ cases and the RS was 34 , indicating a difference of $8 \%$. Genes common to the Oncotype DX and the Biomark assay include marker of proliferation Ki-67, aurora kinase A, Erb-B2 receptor tyrosine kinase 2, glutathione $\mathrm{S}$-transferase $\mathrm{Mu} 1$, estrogen receptor 1, progesterone receptor, B-cell lymphoma 2, signal peptide CUB domain EGF-like 2 and 5 reference genes. The remaining 28 genes are involved in various pathways and functions. This result indicates that there is a significant correlation between PS and RS scores, although validation of results is required to accurately determine the risk of distant recurrence. The Biomark assay is an easy and inexpensive way to measure mRNA expression. The present
\end{abstract}

Correspondence to: Dr Chungyeul Kim, Department of Pathology, Korea University Guro Hospital, 148 Gurodong-ro, Guro-gu, Seoul 08308, Republic of Korea

E-mail: idea1@hanmail.net

Key words: estrogen receptor, breast cancer, Oncotype DX, Biomark assay, chemotherapy study demonstrates the possibility of the Biomark assay as an alternative for defining chemotherapy benefit in individual patients with ER-positive early-stage breast cancer.

\section{Introduction}

Decisions regarding chemotherapy on the basis of clinicopathological features alone remains unclear for patients with estrogen receptor (ER)-positive, human epidermal growth factor receptor type 2-negative, lymph node-negative breast cancer (1-3). A number of multigene-based assays have emerged to predict the risk of distant recurrence and the benefit of chemotherapy in patients with early-stage breast cancer (4-8). The current National Comprehensive Cancer Network guidelines for Breast Cancer recommends the 21-gene recurrence score $(\mathrm{RS})$ test for the management of patients with ER-positive, early-stage, lymph node-negative breast cancer measuring $>0.5 \mathrm{~cm}$ in size $(4,9)$.

The Oncotype DX assay has been developed to assess the risk of distant recurrence (10). This test uses an algorithm to calculate a RS on a scale of 0 to 100 , which is used to categorize patients into 3 risk groups: Low $(\mathrm{RS}<18)$; intermediate (RS 18-30); and high ( $R S \geq 31$ ), using specified cut-off points to classify each patient (10-13). The RS has been validated by estimating the rate of distant recurrence following 10 years through large-scale clinical trials, including the National Surgical Adjuvant Breast and Bowel Project B-20 in patients with breast cancer. The rate in the low-risk group was significantly lower compared with that in the high-risk group. The Oncotype DX assay provides predictive power for distant recurrence according to RS and a significant correlation has been identified between chemotherapy treatment and RS $(1,10,14,15)$. However, due to the cost of the Oncotype DX assay and a number of additional turnaround times, it is not commonly performed in the majority of cases of patients with breast cancer (16). For example, in Korea, the cost of the test is quite high, as the assay is performed abroad (9).

Therefore, the objective of the present study was to examine whether the Biomark assay system could be a substitute for the Oncotype DX RS assay, using a dynamic array chip. This assay may serve as a beneficial tool to evaluate the prognosis of breast cancer by predicting the risk of distant recurrence, and individually judging the necessity of chemotherapy in patients with ER-positive, early-stage breast cancer. 


\section{Materials and methods}

Sample preparation. Formalin-fixed paraffin-embedded (FFPE) tissues $(n=50)$ from patients with early-stage ER-positive breast cancer, who underwent the Oncotype DX test (Genomic Health Inc., Redwood City, CA, USA) following surgery, were used for RNA extraction. The FFPE blocks and paired hematoxylin and eosin-stained slides were obtained from the Department of Pathology at Korea University Guro Hospital (Seoul, Korea). All patients were female and their ages ranged between 32-80 years (median, 52.42 years). The stage of patients were classified according to internationally recognized guidelines for breast cancer (Table I) (17). The present study was approved by the Institutional Review Board of the Korea University Guro Hospital (approval no. KUGH 17046; Seoul, Korea). All participants provided written informed consent. A skilled pathologist at Korea University Guro Hospital (Seoul, Korea) used a light microscope (magnification, x100) to examine the hematoxylin and eosin-stained slides and select blocks with sufficient tumor cells. A total of $6(10-\mu \mathrm{m}$ thick) sections from each FFPE block were deparaffinized by xylene at a heating temperature of $50^{\circ} \mathrm{C}$, followed by ethanol washing, and RNA was subsequently isolated using a RNeasy FFPE kit (Qiagen GmbH, Hilden, Germany), according to the manufacturer's protocols, with DNase I treatment. RNA quantities and purities were first measured with the NanoDrop 2000 spectrophotometer (Thermo Fisher Scientific, Inc., Waltham, MA, USA) and used in subsequent evaluations. FFPE tissue is an abundant source of clinical specimens; however, their use is limited in applications involving analysis of gene expression, due to RNA degradation and modification during fixation and processing steps (18). Therefore, the quality of RNA extracted from FFPE is one of the most important factors for a multigene assay and next-generation sequencing (19).

Selection of 149 candidate genes. To select genes for analysis, the Oncotype DX RS values were applied to a publicly available microarray dataset with a correlation between the RS and individual genes. A total of seven datasets GSE7390, GSE2034, GSE2990, GSE4922, GSE12093, GSE3494 and GSE6532 (20) of the Affymetrix platform (21) were used with ER-positive and lymph node-negative samples. The Oncotype DX RS was calculated using 16 genes (10). Finally, the RS values were adjusted from 0 to 100 . The mean correlation with individual genes was determined by the mean of the Pearson's correlation and the Spearman's rank correlation, using the RS score and gene expression level of each sample. A correlation was considered when the mean correlation coefficient from the 7 data-sets was $\geq 0.5$ and the final candidate gene group was selected in this process. A total of 149 candidate genes, including all Oncotype DX genes with a high correlation based on the Oncotype DX RS were identified, in another project, which enrolled $>300$ Korean patients with ER-positive breast cancer. Since this project is still ongoing, the presentation of all the genes and sequences was not possible.

Reverse transcription $(R T)$ and pre-amplification of cDNA. For cDNA synthesis, 250 ng of total RNA was reverse-transcribed using a Reverse Transcription Master mix (Fluidigm, San Francisco, CA, USA) in $5 \mu$ reactions, according to manufacturer's protocols. Detecting the specific target genes requires a minimum of 800 copies $/ \mu 1$ in the final sample mix and pre-amplification can increase the number of copies to a detectable level. The pre-amplification method of cDNA enables the expression studies with a large number of genes from a limited number of samples, including tissue biopsies and archival FFPE materials $(18,22)$. The cDNA samples were amplified with PreAmp Master mix (Fluidigm) and 149 custom-designed primers using Delta Gene assays (Fluidigm), according to the manufacturer's protocols. For pooling the Delta Gene assay, $1 \mu \mathrm{l}$ of each Delta Gene assay (up to 96 assays and up to 53 assays) was combined and added to a DNA suspension buffer (10 mM Tris and $0.1 \mathrm{mM}$ EDTA, pH 8.0; Teknova, Inc., Hollister, CA, USA) to produce a final volume of $200 \mu \mathrm{l}$ for the final concentration of each assay (500 nM). PreAmp Master mix, pooled primers and cDNA were mixed in a PCR plate. Pre-amplification reactions were performed on the Applied Biosystems Veriti thermal cycler (Thermo Fisher Scientific, Inc.) using the following cycling conditions: $95^{\circ} \mathrm{C}$ for $2 \mathrm{~min}$, followed by 14 cycles of $95^{\circ} \mathrm{C}$ for $15 \mathrm{sec}$ and $60^{\circ} \mathrm{C}$ for $4 \mathrm{~min}$. Exonuclease I (New England BioLabs, Inc., Ipswich, MA, USA) was subsequently added to each pre-amplification reaction, to eliminate the carryover of unincorporated primers. The samples were incubated in the thermal cycler at $37^{\circ} \mathrm{C}$ for $30 \mathrm{~min}$ and at $80^{\circ} \mathrm{C}$ for $15 \mathrm{~min}$ for inactivation. Following pre-amplification, the final products were diluted to $1: 10(\mathrm{v} / \mathrm{v})$ in TE buffer $(10 \mathrm{mM}$ Tris-HCI, 1.0 mM EDTA, pH 8.0; Teknova, Inc.).

$R T$-quantitative polymerase chain reaction ( $R T-q P C R)$. The Biomark system (Fluidigm) provides orders of magnitude of a higher throughput for RT-qPCR, compared with the conventional platforms, due to its dynamic array integrated fluidic circuits (IFCs) (Fluidigm). These nanofluidic chips contain fluidic networks that automatically combine sets of samples with sets of assays. The control line fluid (Fluidigm) was injected into each accumulator on 96.96 dynamic array IFC chip and placed the chip into the IFC controller for priming. The pre-amplified sample was subsequently mixed with SsoFast EvaGreen supermix with low ROX (Bio-Rad Laboratories, Inc., Hercules, CA, USA), according to the manufacturer's protocols, and DNA binding dye sample loading reagent (Fluidigm) were loaded into each inlet on the right side of the frame at room temperature. For the other 96 wells, primer pairs combined with assay loading reagent (Fluidigm) and DNA suspension buffer (10 mM Tris-HCl, $0.1 \mathrm{mM}$ EDTA, pH 8.0; Fluidigm) were loaded into their respective inlets. Once in the wells, the components are pressurized into the microfluidic chip using an IFC controller and subsequently systematically combined into 9216 parallel reactions. RT-qPCR was performed on a Biomark HD system using the following thermocycling conditions: $70^{\circ} \mathrm{C}$ for $2,400 \mathrm{sec}, 60^{\circ} \mathrm{C}$ for $30 \mathrm{sec}, 95^{\circ} \mathrm{C}$ for $60 \mathrm{sec}$, followed by 30 cycles of $96^{\circ} \mathrm{C}$ for $5 \mathrm{sec}$ and $60^{\circ} \mathrm{C}$ for $20 \mathrm{sec}$. The Biomark assays were repeated twice to provide projects 1 and 2. Data were processed by an automatic global method to set the same threshold value for all assays (23) and a linear derivative was used as the baseline correction method using Real-Time PCR Analysis 4.1.3 software (Fluidigm). The cycle quantification $(\mathrm{Cq})$ values of 149 genes were obtained using a Biomark HD system (National Instrumentation Center for 
Table I. Patient and tumor characteristics.

\begin{tabular}{|c|c|}
\hline Characteristic & Number $(\%$ \\
\hline Number of cases & 50 \\
\hline \multicolumn{2}{|l|}{ Age (years) } \\
\hline$<40$ & $2(4)$ \\
\hline $40-49$ & $21(42)$ \\
\hline $50-59$ & $20(40)$ \\
\hline$\geq 60$ & $7(14)$ \\
\hline \multicolumn{2}{|l|}{ Surgery } \\
\hline Breast-conserving operation & $46(92)$ \\
\hline Mastectomy & $4(8)$ \\
\hline \multicolumn{2}{|l|}{ Pathological T stage $^{\mathrm{a}}$} \\
\hline $\mathrm{T} 1$ & $48(96)$ \\
\hline $\mathrm{T} 2$ & $2(4)$ \\
\hline \multicolumn{2}{|l|}{ Pathological N stage ${ }^{a}$} \\
\hline No & $50(100)$ \\
\hline \multicolumn{2}{|l|}{ Histological subtype } \\
\hline Ductal carcinoma & $44(88)$ \\
\hline Lobular & $6(12)$ \\
\hline \multicolumn{2}{|l|}{ Nuclear grade ${ }^{b}$} \\
\hline 1 & $16(32)$ \\
\hline 2 & $31(62)$ \\
\hline 3 & $3(6)$ \\
\hline \multicolumn{2}{|l|}{ Histological grade ${ }^{\mathrm{b}}$} \\
\hline 1 & $34(68)$ \\
\hline 2 & $16(32)$ \\
\hline \multicolumn{2}{|l|}{ Estrogen receptor ${ }^{\mathrm{c}}$} \\
\hline Positive & $50(100)$ \\
\hline Negative & 0 \\
\hline \multicolumn{2}{|l|}{ Progesterone receptor $^{\mathrm{c}}$} \\
\hline Positive & $46(92)$ \\
\hline Negative & $4(8)$ \\
\hline \multicolumn{2}{|l|}{$\mathrm{Ki}-67^{\mathrm{d}}$} \\
\hline Low & $31(62)$ \\
\hline High & $19(38)$ \\
\hline \multicolumn{2}{|l|}{ Radiotherapy } \\
\hline Yes & $42(84)$ \\
\hline No & $8(16)$ \\
\hline \multicolumn{2}{|l|}{ Chemotherapy } \\
\hline Yes & $19(38)$ \\
\hline No & $31(62)$ \\
\hline \multicolumn{2}{|l|}{ Endocrine therapy } \\
\hline Yes & $50(100)$ \\
\hline No & 0 \\
\hline
\end{tabular}

The disease stages of the patients were determined by athe 8th edition of the American Joint Committee on Cancer cancer staging manual; ${ }^{\mathrm{b}}$ modified Bloom-Richardson grade; ${ }^{\mathrm{c} A m e r i c a n}$ Society of Clinical Oncology/College of American Pathologists guidelines for immunohistochemistry testing; and ${ }^{\mathrm{d}}$ St. Gallen International Breast Cancer Conference 2015.
Environmental Management, Seoul National University, Seoul, Korea). Gene expression was quantified using $2^{-\Delta \Delta C q}$ method (24) and melting point curves, through the Biomark assay system in 50 samples.

Statistical analysis. The mean expression of five reference genes [actin $\beta(A C T B), G A P D H$, glucuronidase $\beta(G U S B)$, ribosomal protein lateral stalk subunit P0 $(R P L P O)$ and transferrin receptor (TFRC)] was used to normalize the expression of 144 genes prior to analyzing the correlation with the Oncotype DX RS. Further data analysis was performed in BRB-ArrayTools Beta 2 4.6.0 software (National Institutes of Health, Bethesda, MD, USA). Subsequent to importing the normalized data on BRB ArrayTools, a 'quantitative trait analysis' was performed. Using the least angle regression (LAR) algorithm in the BRB-ArrayTools software and the column RS for defining a response, the 41 genes that correlated with $\mathrm{RS}$ were identified, in addition to the following formula for prediction. The prediction of the present study's samples can be calculated by the formula: $\sum$ icixi-10.809, where ci and xi are the coefficient and gene expression for the $\mathrm{i}$-th gene, respectively. Three cut-off values of $\geq 18, \geq 11$ and $\leq 10$ were used to determine the need for chemotherapy compared with RS.

\section{Results}

Patient and tumor characteristics. Between 2012-2017, a total of 50 patients had an Oncotype DX RS test. Patients' ages ranged between 32-80 years of age and the median age was 52.42 years. The detailed characteristics of the patients are presented in Table I, where data from 50 patients with a RS of 0-29 were included in these analyses.

Correlation between Oncotype DX RS and Biomark assay. A quantitative trait analysis was performed to select significant genes through BRB ArrayTools, which indicated 36 genes that correlated with RS from 144 candidate genes, except for the 5 reference genes used for normalization, using the LAR algorithm. The coefficient of each gene was also presented in Table II. Oncotype DX assay panel of 16 cancer-associated genes and 5 reference genes (ACTB, GAPDH, GUSB, RPLPO, and $T F R C$ ) were also included in the Biomark assay. As indicated in Table III, a total of 41 genes were selected from Biomark assay. As a result, 13 genes, including 5 reference genes, were identified from Oncotype DX and 28 genes were confirmed from the Biomark assay in the present study. Genes common to the Oncotype DX test and the Biomark assay are marker of proliferation Ki-67 (MKI67), aurora kinase A (AURKA), Erb-B2 receptor tyrosine kinase 2 (ERBB2), glutathione S-transferase Mu 1 (GSTMI), estrogen receptor 1 (ESRl), progesterone receptor $(P G R)$, B-cell lymphoma 2 (BCL2), signal peptide CUB domain EGF-like 2 (SCUBE2), in addition to 5 reference genes. Since the predicted error rate according to the number of genes increases, it is necessary to verify the present study's results in the future.

Predicted score (PS) vs. Oncotype DX RS. The PS was obtained by the coefficient (Table II), and the normalized log intensities for significant genes, which were subsequently compared with the RS, marked the actual score for each patient's prediction. 
Table II. The selected genes and the coefficient from the Biomark assay.

\begin{tabular}{|c|c|}
\hline Selected genes & Coefficient \\
\hline CDKN3 & 0.446 \\
\hline CDK1 & 1.452 \\
\hline CDC6 & -0.386 \\
\hline AURKA & 2.928 \\
\hline ESR1 & -2.105 \\
\hline DNMT3B & 2.03 \\
\hline BUB1 & -0.762 \\
\hline CDCA3 & -1.747 \\
\hline PGR & -1.243 \\
\hline NCAPG2 & -0.821 \\
\hline EZH2 & 1.996 \\
\hline GSTM1 & -0.308 \\
\hline MKI67 & 0.577 \\
\hline LMNB2 & 2.769 \\
\hline CCNA2 & -0.833 \\
\hline CENPN & 0.038 \\
\hline PTTG1 & 1.192 \\
\hline SLC25A12 & 0.265 \\
\hline DLGAP5 & -0.569 \\
\hline ERBB2 & 1.765 \\
\hline KIF20A & -1.389 \\
\hline SCUBE2 & -1.141 \\
\hline KIF11 & -0.696 \\
\hline RRM2 & -0.067 \\
\hline CCNE2 & 0.198 \\
\hline BCL2 & -0.568 \\
\hline SQLE & 0.536 \\
\hline LRRC48 & -0.221 \\
\hline CX3CR1 & 0.349 \\
\hline NCAPH & -0.892 \\
\hline C16orf61 & 0.92 \\
\hline KIF15 & -0.267 \\
\hline PDSS1 & -0.598 \\
\hline PRC1 & -1.535 \\
\hline CIRBP & 0.315 \\
\hline GTSE1 & -0.252 \\
\hline
\end{tabular}

Results indicated that $31 / 50(62 \%)$ cases were defined as a low-risk group (RS <18) and 19/50 (38\%) were defined as an intermediate-risk group (RS 18-30; Table IV). The RS algorithm was designed by analyzing the results of the three independent preliminary studies (10). The PS of 50 samples was calculated by the following formula: $\sum$ icixi-10.809, where 'ci' and 'xi' are the coefficient and gene expression for the i-th gene, respectively. Sample no. 8 indicated a large discrepancy between PS and RS. The assay was repeated with the same mRNA, and PS and RS values exhibited similar high scores in the two Biomark assays, indicating the stability of the assay itself. It was speculated, however, that sample no. 8 may have problems, including high degradation rate.
Table III. Genetic comparison between Oncotype DX and Biomark assay.

\begin{tabular}{|c|c|c|}
\hline $\begin{array}{l}\text { Oncotype DX } \\
\text { genes }(n=21)\end{array}$ & $\begin{array}{c}\text { Common } \\
\text { genes }(n=13)\end{array}$ & $\begin{array}{c}\text { Biomark assay } \\
\text { genes }(n=41)\end{array}$ \\
\hline BIRC5 & MKI67 & CDK1 \\
\hline CCNB1 & AURKA & CDC6 \\
\hline MYBL2 & ERBB2 & CDCA3 \\
\hline MMP11 & GSTM1 & NCAPG2 \\
\hline CTSL2 & ESR1 & LMNB2 \\
\hline GRB7 & PGR & CENPN \\
\hline BAG1 & BCL2 & PTTG1 \\
\hline \multirow[t]{21}{*}{ CD68 } & SCUBE2 & CCNE2 \\
\hline & ACTB & SQLE \\
\hline & GAPDH & LRRC48 \\
\hline & RPLP0 & KIF15 \\
\hline & GUSB & PDSS1 \\
\hline & TFRC & PRC1 \\
\hline & & CIRBP \\
\hline & & CDKN3 \\
\hline & & DNMT3B \\
\hline & & BUB1 \\
\hline & & EZH2 \\
\hline & & CCNA2 \\
\hline & & SLC25A12 \\
\hline & & DLGAP5 \\
\hline & & KIF20A \\
\hline & & KIF11 \\
\hline & & RRM2 \\
\hline & & CX3CR1 \\
\hline & & NCAPH \\
\hline & & C16orf61 \\
\hline & & GTSE1 \\
\hline
\end{tabular}

Concordance between PS and Oncotype DX RS. If the cut-off is $\geq 18$, the PS is $18 / 50$ cases $(36 \%)$ and $\mathrm{RS}$ is $19 / 50(38 \%)$, indicating a differential rate of PS against RS of $2 \%$. To minimize the possibility of undertreated patients, if the cut-off is $\geq 11$, PS is $38 / 50(76 \%)$, and $\mathrm{RS}$ is $34 / 50(68 \%)$, indicating a differential rate of $8 \%$ (Table V). Groups with a cut-off value $\leq 10$ are classified as low-risk and do not require chemotherapy. The difference between PS and RS is 10\% (Table V). This result indicates that there is a significant correlation between PS and RS scores, although validation is required to accurately determine the risk of distant recurrence.

\section{Discussion}

Breast cancer is one of the most common types of cancer in females globally, and accounted for $25.2 \%$ of all female cancer cases in 2012 (25). Furthermore, in Korea, breast cancer is the second most common type of cancer among females, following thyroid cancer. In 2013, its incidence accounted for 
Table IV. The predicted score and the actual recurrence score for each patient's prediction.

\begin{tabular}{|c|c|c|}
\hline $\begin{array}{l}\text { Sample } \\
\text { code }\end{array}$ & $\begin{array}{l}\text { Predicted } \\
\text { score }\end{array}$ & $\begin{array}{l}\text { Actual } \\
\text { recurrence score }\end{array}$ \\
\hline 1 & 14 & 17 \\
\hline 2 & 14 & 29 \\
\hline 3 & 22 & 28 \\
\hline 4 & 25 & 22 \\
\hline 5 & 19 & 22 \\
\hline 6 & 15 & 14 \\
\hline 7 & 25 & 21 \\
\hline 8 & 31 & 5 \\
\hline 9 & 6 & 0 \\
\hline 10 & 24 & 15 \\
\hline 11 & 21 & 20 \\
\hline 12 & 6 & 10 \\
\hline 13 & 16 & 17 \\
\hline 14 & 15 & 6 \\
\hline 15 & 8 & 7 \\
\hline 16 & 16 & 16 \\
\hline 17 & 20 & 23 \\
\hline 18 & 14 & 9 \\
\hline 19 & 12 & 9 \\
\hline 20 & 24 & 24 \\
\hline 21 & 10 & 11 \\
\hline 22 & 14 & 10 \\
\hline 23 & 18 & 28 \\
\hline 24 & 0 & 2 \\
\hline 25 & 4 & 9 \\
\hline 26 & 18 & 22 \\
\hline 27 & 7 & 10 \\
\hline 28 & 18 & 21 \\
\hline 29 & 11 & 13 \\
\hline 30 & 16 & 20 \\
\hline 31 & 11 & 5 \\
\hline 32 & 13 & 23 \\
\hline 33 & 19 & 17 \\
\hline 34 & 16 & 14 \\
\hline 35 & 18 & 16 \\
\hline 36 & 7 & 4 \\
\hline 37 & 14 & 11 \\
\hline 38 & 11 & 10 \\
\hline 39 & 25 & 25 \\
\hline 40 & 17 & 15 \\
\hline 41 & 7 & 12 \\
\hline 42 & 16 & 15 \\
\hline 43 & 23 & 20 \\
\hline 44 & 10 & 17 \\
\hline 45 & 9 & 0 \\
\hline 46 & 23 & 19 \\
\hline 47 & 21 & 23 \\
\hline 48 & 13 & 18 \\
\hline 49 & 22 & 26 \\
\hline 50 & 7 & 9 \\
\hline
\end{tabular}

Table V. Comparison of cut-off criteria for screening for chemotherapy.

\begin{tabular}{lccccc}
\hline & \multicolumn{2}{c}{ PS } & & \multicolumn{2}{c}{ Actual RS } \\
\cline { 2 - 3 } \cline { 5 - 6 } Criteria & $\begin{array}{c}\text { No. of cases } \\
(\mathrm{n}=50)\end{array}$ & $\%$ & & $\begin{array}{c}\text { No. of cases } \\
(\mathrm{n}=50)\end{array}$ & $\%$ \\
\hline Cut-off $\geq 18$ & 18 & 36 & 19 & 38 \\
Cut-off $\geq 11$ & 38 & 76 & & 34 & 68 \\
Cut-off $\leq 10$ & 11 & 22 & & 16 & 32 \\
\hline
\end{tabular}

PS, predicted score; RS, recurrence score.

$15.4 \%$ of all cases of cancer in females and the mortality rate nearly doubled in 3 years following 2010 (26). According to the statistics of the Korea Central Cancer Registry database, a total of 21,484 novel cases of breast cancer were diagnosed in $2014(26,27)$.

In 2014, cases of hormone receptor-positive breast cancer were indicated to be consistently increasing, reaching $74.1 \%$ of all breast cancer cases. The ratio of early breast cancer with stage 0 and stage I was reported in 2014 to have increased gradually, and accounted for $\geq 50 \%$ of all breast cancer cases in Korea (26). Patients with hormone receptor-positive early-stage breast cancer can be treated solely with endocrine therapy, without adjuvant chemotherapy, following surgery. In the absence of multigene testing, the majority of patients underwent chemotherapy as an adjuvant treatment to prevent recurrence. It has been observed that some females are undertreated for their disease, while others are overtreated (28). As a result, patients suffer from numerous side effects including vomiting, diarrhea, fever and hair loss, resulting in unnecessary expenditure by the national healthcare system. However, patients do not receive equal clinical benefits from chemotherapy and only $4-5 \%$ of these patients actually benefit from adjuvant chemotherapy (1). That is why multigene testing is necessary to determine whether or not to perform chemotherapy in patients, therefore, increasing the importance of examining multigene prognostic tools (29-31). Among them, the 21-gene RS assay has been the most frequently used and proven to have a significant impact on treatment decisions for patients with early breast cancer (1,32-35). However, the cost of the 21-gene assay is high, in addition to the turnaround time to get results from abroad (16). Therefore, further studies for an economical alternative to Oncotype DX are required.

In the present study, 41 genes were selected through the Biomark assay system. Common genes of Oncotype DX and Biomark assay were used, including MKI67, AURKA, ERBB2, GSTM1, ESR1, PGR, BCL2, SCUBE2 and 5 reference genes. The remaining 28 genes are involved in various pathways and functions, including the cell cycle. It can be suggested that there is a distinct difference from the Oncotype DX in the genetic composition designed from a study of Korean patients with breast cancer. If the score was $\geq 18$, the predicted model indicated a differential rate of $2 \%$ against RS. To minimize the potential for patient undertreatment, if the score was $\geq 11$, a differential rate of $8 \%$ was identified. The present study's PS 
provided an accurate reflection of the RS. Sample no. 8 had the highest score among 50 samples and had a large discrepancy between PS and RS. The assay was repeated with the same mRNA, and PS and RS values tended to exhibit a high score in the two Biomark assays (Project 1 and 2), indicating the stability of the assay itself. Sample no. 8 itself may have problems, including high degradation rate, however, the sample could not be excluded for analysis without specific reason. Further studies are to be conducted to verify the validity of the algorithm using an independent sample set. Depending on the results of the aforementioned, it would assist to discern the limitation of the Biomark assay.

Samples of patients with low-risk, ER-positive early-stage breast cancer were used in the present study. However, it is necessary to analyze samples of high-risk patients prone to relapse for future validation of the algorithm. Oncotype DX is a valuable test for deciding the optimal treatment for each individual case of breast cancer. However, it is not affordable for developing countries and therefore a novel test is required to replace Oncotype DX.

\section{Acknowledgements}

The authors acknowledge the National Instrumentation Center for Environmental Management at Seoul National University (Seoul, Korea) for their assistance in the present study.

\section{Funding}

The present study was supported by the National Research Foundation of Korea (grant no. 2017R1C1B1011803) and the Korea Health Industry Development Institute (grant no. HI14C3405).

\section{Availability of data and materials}

The datasets used and/or analyzed during the current study are available from the corresponding author on reasonable request.

\section{Authors' contributions}

JK, AK and CK designed the study. JK collected clinical samples and data. JK and CK drafted the manuscript, and analyzed and interpreted the data. All authors read and approved the final manuscript.

\section{Ethics approval and consent to participate}

Written informed consent was obtained from each patient, and the study protocol and consent procedures were approved by the Institutional Review Board of Korea University Guro Hospital (approval no., KUGH 17046; Seoul, Korea).

\section{Patient consent for publication}

Not applicable.

\section{Competing interests}

The authors declare that they have no competing interests.

\section{References}

1. Paik S, Tang G, Shak S, Kim C, Baker J, Kim W, Cronin M, Baehner FL, Watson D, Bryant J, et al: Gene expression and benefit of chemotherapy in women with node-negative, estrogen receptor-positive breast cancer. J Clin Oncol 24: 3726-3734, 2006.

2. Henderson IC and Patek AJ: The relationship between prognostic and predictive factors in the management of breast cancer. Breast Cancer Res Treat 52: 261-288, 1998.

3. Hayes DF, Trock B and Harris AL: Assessing the clinical impact of prognostic factors: When is 'statistically significant' clinically useful? Breast Cancer Res Treat 52: 305-319, 1998.

4. Nagaraj G and Ma CX: Adjuvant chemotherapy decisions in clinical practice for early-stage node-negative, estrogen receptor-positive, HER2-negative breast cancer: Challenges and considerations. J Natl Compr Canc Netw 11: 246-250; quiz 251, 2013.

5. Abramovitz $\mathrm{M}$ and Leyland-Jones B: A systems approach to clinical oncology: Focus on breast cancer. Proteome Sci 4: 5, 2006.

6. Duffy MJ: Predictive markers in breast and other cancers: A review. Clin Chem 51: 494-503, 2005.

7. Van De Vijver MJ, He YD, Van't Veer LJ, Dai H, Hart AA, Voskuil DW, Schreiber GJ,Peterse JL, Roberts C, Marton MJ, et al: A gene-expression signature as a predictor of survival in breast cancer. N Engl J Med 347: 1999-2009, 2002.

8. Sotiriou C, Neo SY, McShane LM, Korn EL, Long PM, Jazaeri A, Martiat P, Fox SB, Harris AL and Liu ET: Breast cancer classification and prognosis based on gene expression profiles from a population-based study. Proc Natl Acad Sci USA 100: 10393-10398, 2003.

9. Lee MH, Han W, Lee JE, Kim KS, Park H, Kim J, Bae SY, Shin HJ, Lee JW and Lee ES: The clinical impact of 21-gene recurrence score on treatment decisions for patients with hormone receptor-positive early breast cancer in Korea. Cancer Res Treat 47: 208-214, 2015.

10. Paik S, Shak S, Tang G, Kim C, Baker J, Cronin M, Baehner FL, Walker MG, Watson D, Park T, et al: A multigene assay to predict recurrence of tamoxifen-treated, node-negative breast cancer. N Engl J Med 351: 2817-2826, 2004

11. Albain KS, Barlow WE, Shak S, Hortobagyi GN, Livingston RB, Yeh IT, Ravdin P, Bugarini R, Baehner FL, Davidson NE, et al: Prognostic and predictive value of the 21-gene recurrence score assay in postmenopausal women with node-positive, oestrogen-receptor-positive breast cancer on chemotherapy: A retrospective analysis of a randomised trial. Lancet Oncol 11: 55-65, 2010.

12. Sparano JA, Gray RJ, Makower DF, Pritchard KI, Albain KS, Hayes DF, Geyer CE Jr, Dees EC, Perez EA, Olson JA Jr, et al: Prospective validation of a 21-gene expression assay in breast cancer. N Engl J Med 373: 2005-2014, 2015.

13. Győrffy B, Hatzis C, Sanft T, Hofstatter E, Aktas B and Pusztai L: Multigene prognostic tests in breast cancer: Past, present, future. Breast Cancer Res 17: 11, 2015

14. Waintraub SE, McNamara D, Graham DMA, Pecora AL, Min J, Wu T, Noh HG, Connors J, Pe Benito R, Choi K, et al: Real-world economic value of a 21-gene assay in early-stage breast cancer. Am J Manag Care 23: e416-e420, 2017.

15. Mamounas EP, Tang G, Fisher B, Paik S, Shak S, Costantino JP, Watson D, Geyer CE Jr, Wickerham DL and Wolmark N: Association between the 21-gene recurrence score assay and risk of locoregional recurrence in node-negative, estrogen receptor-positive breast cancer: Results from NSABP B-14 and NSABP B-20. J Clin Oncol 28: 1677-1683, 2010.

16. Tan AC, Li BT, Nahar K, Danieletto S, Fong ES, Currer T, Parasyn A, Middleton P, Wong H, Smart D, et al: Correlating Ki67 and other prognostic markers with Oncotype DX recurrence score in early estrogen receptor-positive breast cancer. Asia Pac J Clin Oncol 14: e161-e166, 2017.

17. Giuliano AE, Connolly JL, Edge SB, Mittendorf EA, Rugo HS, Solin LJ, Weaver DL, Winchester DJ and Hortobagyi GN: Breast cancer-major changes in the American Joint Committee on Cancer eighth edition cancer staging manual. CA Cancer J Clin 67: 290-303, 2017.

18. Li J, Smyth P, Cahill S, Denning K, Flavin R, Aherne S, Pirotta M, Guenther SM, O'Leary JJ and Sheils O: Improved RNA quality and TaqMan Pre-amplification method (PreAmp) to enhance expression analysis from formalin fixed paraffin embedded (FFPE) materials. BMC Biotechnol 8: 10, 2008. 
19. Choi Y, Kim A, Kim J, Lee J, Lee SY and Kim C: Optimization of RNA extraction from formalin-fixed paraffin-embedded blocks for targeted next-generation sequencing. J Breast Cancer 20: 393-399, 2017.

20. Györffy B, Lanczky A, Eklund AC, Denkert C, Budczies J, Li Q and Szallasi Z: An online survival analysis tool to rapidly assess the effect of 22,277 genes on breast cancer prognosis using microarray data of 1,809 patients. Breast Cancer Res Treat 123: 725-731, 2010.

21. Győrffy B, Benke Z, Lánczky A, Balázs B, Szállási Z, Timár J and Schäfer R: RecurrenceOnline: An online analysis tool to determine breast cancer recurrence and hormone receptor status using microarray data. Breast Cancer Res Treat 132: 1025-1034, 2012.

22. Vermeulen J, Derveaux S, Lefever S, De Smet E, De Preter K, Yigit N, De Paepe A, Pattyn F, Speleman F and Vandesompele J: RNA pre-amplification enables large-scale RT-qPCR gene-expression studies on limiting sample amounts. BMC Res Notes 2: 235, 2009.

23. Devonshire AS, Elaswarapu R and Foy CA: Applicability of RNA standards for evaluating RT-qPCR assays and platforms. BMC Genomics 12: 118, 2011.

24. Livak KJ and Schmittgen TD: Analysis of relative gene expression data using real-time quantitative PCR and the 2(-Delta Delta C(T)) method. Methods 25: 402-408, 2001.

25. Ferlay J, Soerjomataram I, Dikshit R, Eser S, Mathers C, Rebelo M, Parkin DM, Forman D and Bray F: Cancer incidence and mortality worldwide: Sources, methods and major patterns in GLOBOCAN 2012. Int J Cancer 136: E359-E386, 2015.

26. Park EH, Min SY, Kim Z, Yoon CS, Jung KW, Nam SJ, Oh SJ, Lee S, Park BW, Lim W, et al: Basic facts of breast cancer in Korea in 2014: The 10-year overall survival progress. J Breast Cancer 20: 1-11, 2017.

27. Hwang KT, Kim EK, Jung SH, Lee ES, Kim SI, Lee S, Park HK, Kim J, Oh S and Kim YA; Korean Breast Cancer Society: Tamoxifen therapy improves overall survival in luminal A subtype of ductal carcinoma in situ: A study based on nationwide Korean Breast Cancer Registry database. Breast Cancer Res Treat 169: 311-322, 2018.
28. Cronin M, Sangli C, Liu ML, Pho M, Dutta D, Nguyen A, Jeong J, Wu J, Langone KC and Watson D: Analytical validation of the Oncotype DX genomic diagnostic test for recurrence prognosis and therapeutic response prediction in node-negative, estrogen receptor-positive breast cancer. Clin Chem 53: 1084-1091, 2007.

29. Mariotto A, Feuer EJ, Harlan LC, Wun LM, Johnson KA and Abrams J: Trends in use of adjuvant multi-agent chemotherapy and tamoxifen for breast cancer in the United States: 1975-1999. J Natl Cancer Inst 94: 1626-1634, 2002.

30. Buchholz TA, Stivers DN, Stec J, Ayers M, Clark E, Bolt A Sahin AA, Symmans WF, Hess KR, Kuerer HM, et al: Global gene expression changes during neoadjuvant chemotherapy for human breast cancer. Cancer J 8: 461-468, 2002.

31. Perou CM, Sørlie T, Eisen MB, van de Rijn M, Jeffrey SS, Rees CA, Pollack JR, Ross DT, Johnsen H, Akslen LA, et al: Molecular portraits of human breast tumours. Nature 406: 747-752, 2000.

32. Fisher B, Dignam J, Wolmark N, DeCillis A, Emir B, Wickerham DL, Bryant J, Dimitrov NV, Abramson N, Atkins JN, et al: Tamoxifen and chemotherapy for lymph node-negative, estrogen receptor-positive breast cancer. J Natl Cancer Inst 89: 1673-1682, 1997.

33. Paik S, Shak S, Tang G, Kim C, Baker J, Cronin M, Baehner R, Walker M, Watson D, Park T, et al: Multi-gene RT-PCR assay for predicting recurrence in node negative breast cancer patientsNSABP studies B-20 and B-14. Breast Cancer Res Treat 82: 10-11, 2003.

34. Jessup JM, Lively TG and Taube SE: Program for the Assessment of Clinical Cancer Tests (PACCT): Implementing promising assays into clinical practice. Expert Rev Mol Diagn 5: 271-273, 2005.

35. Tsoi DT, Inoue M, Kelly CM, Verma S and Pritchard KI: Cost-effectiveness analysis of recurrence score-guided treatment using a 21-gene assay in early breast cancer. Oncologist 15 : 457-465, 2010.

This work is licensed under a Creative Commons Attribution-NonCommercial-NoDerivatives 4.0 International (CC BY-NC-ND 4.0) License. 